\title{
Characterization of Engineering Elastic Parameters of Oriented Strand Board (OSB) Manufactured from Poplar (Populus delfoides) Strands Using Ultrasonic Contact Pulse Transmission
}

\section{Karakterizacija parametara elastičnosti ploče s orijentiranim makroiverjem (OSB) proizvedene od iverja drva topole (Populus deltoides) uz pomoć ultrazvučnoga kontaktnog prijenosa impulsa}

Original scientific paper $\bullet$ Izvorni znanstveni rad

Received-prispjelo: 15. 2. 2019.

Accepted-prihvaćeno: 20. 11. 2019.

UDK: $630 * 863.21$

https://doi.org/10.5552/drvind.2020.1908

\begin{abstract}
When using wood and wood-based composites, it is necessary to determine the elastic constants of these engineered materials. Oriented strand board (OSB), as structural wood based panel, plays a significant role in the building sector, but the accessibility of such elastic constants of OSB is mostly limited. For this purpose, this study aimed at determining the elastic wave velocity, stiffness and all elastic constants of OSB made from Poplar (Populus deltoides) strands using ultrasonic through-transmission technique. Laboratory OSBs with the mean density of $760 \mathrm{~kg} / \mathrm{m}^{3}$ were made with the average strand sizes of $0.6 \mathrm{~mm}$ in thickness, $120 \mathrm{~mm}$ in length and 30 $\mathrm{mm}$ in width. $8 \%$ phenol-formaldehyde (PF) resin was used with the pressing conditions of $3.43 \mathrm{~N} / \mathrm{mm}^{2}, 190{ }^{\circ} \mathrm{C}$ and $600 \mathrm{~s}$ as pressure, temperature and time of pressing, respectively. The OSBS were assumed as an orthotropic model. Three modulus of elasticity $\left(E_{1}, E_{2}\right.$, and $\left.E_{3}\right)$, three shear modulus $\left(G_{12}, G_{13}\right.$ and $\left.G_{23}\right)$, and six Poisson's ratios $\left(v_{12}, v_{21}, v_{13}, v_{31}, v_{23}, v_{32}\right)$ were calculated by longitudinal, transversal and quasi-transversal waves velocities. Ultrasonically determined stiffness coefficients of OSB were investigated by representative volume elements
\end{abstract}

\footnotetext{
Authors are professor and assistant at Department of Wood and Paper Science and Technology, Natural Resources Faculty, Tarbiat Modares University, Tehran, Iran.

2 Author is professor at Institute for Mechanics of Materials and Structures, Vienna University of Technology (TU Wien), Karlsplatz 13/202, A-1040 Vienna, Austria.

3 Author is professor at Department of Mechanical Engineering, Babol Noshirvani University of Technology, P. O. 484, Babol, Mazandaran, Iran.
} 
(RVE). Therefore, the separation of scales requirement is satisfied, and the measured velocities can be applied to determine the engineering elastic parameters of the examined OSB. The results indicate that modulus of elasticity and shear modulus are in the same order of magnitude in comparison with other references, and the values of Poisson's ratios are valid in ultrasonic range measurement. In conclusion, the ultrasonic contact pulse transmission shows great potential to determine the characterization of elastic wave velocity, stiffness and engineering elastic parameters.

Keywords: poplar (opulus deltoides); oriented strand bord; engineering parameters; ultrasonic waves

SAŽETAK • Za primjenu drva i kompozita na bazi drva iznimno je važno odrediti konstante elastičnosti tih konstrukcijskih materijala. Ploča s orijentiranim makroiverjem (OSB ploča), kao strukturna ploča na bazi drva, ima široku primjenu u građevnom sektoru, a pristup takvim konstantama elastičnosti OSB ploča uglavnom je ograničen. Stoga je cilj ove studije bio odrediti brzinu elastičnog vala, krutost i sve konstante elastičnosti OSB ploča proizvedenih od makroiverja topole (Populus deltoides) primjenom ultrazvučne tehnike. Od iverja prosječne debljine 0,6 mm, duljine $120 \mathrm{~mm}$ i širine $30 \mathrm{~mm}$ laboratorijski su izrađđene OSB ploče srednje gustoće $760 \mathrm{~kg} /$ $\mathrm{m}^{3}$. Upotrijebljena je $8 \%$-tna fenol-formaldehidna (PF) smola u ovim uvjetima prešanja: tlak je bio $3,43 \mathrm{~N} / \mathrm{mm}^{2}$, temperatura $190^{\circ} \mathrm{C}$, a proces prešanja trajao je 600 s. Pretpostavljeno je da su OSB ploče ortotropni modeli. Na temelju srednjih vrijednosti uzdužne, poprečne $i$ kvazipoprečne brzine valova izračunana su tri modula elastičnosti $\left(E_{1}, E_{2} i E_{3}\right)$, tri modula smicanja $\left(G_{12}, G_{13} i G_{23}\right)$ i šest Poissonovih omjera $\left(v_{12}, v_{21}, v_{13}, v_{31}, v_{23}, v_{32}\right)$. Ultrazvučno utvrđene krutosti OSB ploča ispitivane su reprezentativnim volumnim elementima (RVE). Dakle, ispunjen je zahtjev za odvajanje skala, a izmjerene se brzine mogu primijeniti za određivanje inženjerskih parametara elastičnosti ispitivanih OSB ploča. Rezultati pokazuju da su moduli elastičnosti i moduli smicanja istog reda veličine u usporedbi s drugim referencama, a vrijednosti Poissonovih omjera vrijede u mjerenjima ultrazvučnog raspona. Zaključno, ultrazvučni kontaktni prijenos impulsa pokazuje velik potencijal za određivanje brzine elastičnih valova, krutosti i konstrukcijskih parametara elastičnosti materijala.

Ključne riječi: topola (Populus deltoides); ploča s orijentiranim makroiverjem; konstrukcijski parametri; ultrazvučni valovi

\section{INTRODUCTION}

\section{UVOD}

$\mathrm{OSB}$, as an engineered wood material, has got considerable attention in structural applications in recent years so that today OSB plays a remarkable role in both commercial and residential sectors. OSB is commonly used for wall and roof sheathing, flooring and I-joists. It is also used in different applications such as furniture, reels, pallets and boxes, trailer liners and recreational vehicle flooring (Smulski, 1997; Hiziroglu, 2006). Hence, with increasing applications of OSB, the determination of its mechanical properties is critical for ensuring reliable performance.

Elastic constants of OSB are of substantial importance to both science and technology as they not only describe the mechanical behavior of materials but are also significant for purposes of engineering design. Furthermore, engineering constants are required as input parameters for modern numerical simulation methods such as finite element method (FEM), which is often used in mechanics of engineered materials and civil engineering (Goncalves et al., 2014). As a result, determination of the full set of elastic engineering parameters, including three modulus of elasticity $\left(E_{1}, E_{2}\right.$ and $\left.E_{3}\right)$, three shear modulus $\left(G_{12}, G_{13}\right.$ and $\left.G_{23}\right)$, and six Poisson's ratios $\left(v_{12}, v_{21}, v_{13}, v_{31}, v_{23}, v_{32}\right)$, is essential for a better understanding of the particular elastic behavior of OSB (Bodig and Jayne, 1993; Ozyhar et al., 2013).

The availability of engineering parameters for engineered wood composites such as OSB is often limited and no adequate information can be found in the literatures because some properties such as shear modulus and six Poisson's ratios have never been properly addressed. For this reason, some researchers including Morris et al. (1995) used Poisson's ratio of other woodbased panels such as particleboard for simulating the behavior of OSB employing FEM (Morris et al., 1995). Besides, the conventional static test is the most common experimental technique to determine elastic properties of materials. Determination of the elastic constants by conventional static tests requires complex and expensive equipment, long test time and several specimens with special shape and dimensions (Kazemi Najafi et al., 2005). Measurements of shear modulus and Poisson's ratios are very sophisticated to perform and require very elaborate testing equipment, because it is complex to measure shear stresses and respective strains in the test specimens (Keunecke et al., 2007). To overcome these limitations, some researchers such as Bucur $(1992,2006)$, Bucur and Archer (1984), Kazemi Najafi et al. (2005), Keunecke et al. (2007), Kohlhauser and Hellmich (2012), Ozyhar et al. (2013), Goncalves et al. (2014) and Bader et al. (2016) proposed ultrasonic waves method as a nondestructive, cheap, fast, simple and flexible technique to determine the elastic constants of wood and wood-based composites. Ultrasonic waves can freely propagate in solids and liquids and are reflected at boundaries of internal flaws or change of medium. Accordingly, they are related to properties of the propagation medium. Therefore, the measurement of acoustical quantities, such as propagation velocities and attenuation, provides information about the elastic properties of the material. 
Thus, with taking into account the limitations in availability of elastic constants of OSB, the aim of this study was to characterize elastic wave velocity, stiffness and anisotropic behavior, and also to provide all elastic constants of OSB made from Poplar (Populus deltoides) strands by means of ultrasonic waves.

\section{THEORETICAL BACKGROUND} 2. TEORIJSKE OSNOVE

In an orthotropic material, by the generalized Hook's law, stresses $\sigma_{i j}$ and strains $\varepsilon_{i j}$ are linked by six linear relations $\sigma_{i j}=C_{i j k l}^{i j} \varepsilon_{k l}$, which define the stiffness matrix $C_{i j k l}$ with nine independent constants: six diagonal terms and three off-diagonal terms:

$$
\left[\begin{array}{c}
\sigma_{1} \\
\sigma_{2} \\
\sigma_{3} \\
\sigma_{4} \\
\sigma_{5} \\
\sigma_{6}
\end{array}\right]=\left[\begin{array}{cccccc}
C_{11} & C_{12} & C_{13} & 0 & 0 & 0 \\
0 & C_{22} & C_{23} & 0 & 0 & 0 \\
0 & 0 & C_{33} & 0 & 0 & 0 \\
0 & 0 & 0 & C_{44} & 0 & 0 \\
0 & 0 & 0 & 0 & C_{55} & 0 \\
0 & 0 & 0 & 0 & 0 & C_{66}
\end{array}\right]\left[\begin{array}{c}
\varepsilon_{1} \\
\varepsilon_{2} \\
\varepsilon_{3} \\
\varepsilon_{4} \\
\varepsilon_{5} \\
\varepsilon_{6}
\end{array}\right]
$$

Where $\sigma, C$ and $\varepsilon$ are stress, stiffness and strain tensors, respectively

The relations between the terms of the stiffness matrix and the ultrasonic wave velocity are well known by the Christoffel's equation (Ozyhar et al., 2013; Bucur, 1992):

$$
\left[\Gamma_{i k}-\rho V^{2} \delta_{i k}\right]=0,
$$

Where $\Gamma_{i k}$ is Christoffel's tensor, $\delta_{i k}$ is the Kronecker delta symbol, $V$ is the wave velocity and $\rho$ is the density of the solid. The eigenvalues and eigenvectors of Christoffel's tensor, and stiffness tensor components can be calculated from the mass density of the material, and from the ultrasonic wave velocities, according to the theory of wave propagation in elastic media (Ozyhar et al., 2013; Bucur, 1992):

$$
C_{i j}=V_{i j}^{2} \rho
$$

Where the first index $i$ of the velocities $V_{i, j}$ designates the wave propagation direction, and the second index $j$ designates the direction of the particle motion induced by the wave, i.e. the polarization direction ( $i=$ $j$ for a longitudinal wave; $i \neq j$ for a transversal wave).

Accordingly, the normal stiffness tensor components $C_{11}, C_{22}$, and $C_{33}$ are related to longitudinal wave velocities $V_{11}, V_{22}$, and $V_{33}$ (Eq. 4); while the shear stiffness components $C_{44}, C_{55}$, and $C_{66}$, which are equal to the shear moduli $G_{12}, G_{13}$, and $G_{23}$, respectively, are related to transversal wave velocities $V_{12} / V_{21}, V_{13} / V_{31}$ and $V_{23} / V_{32}$ (Eq. 5). For the determination of off-diagonal terms $C_{i i j j}$, the propagation of ultrasonic waves along non-principal directions in symmetry planes is necessary. For propagation directions in symmetry planes inclined by $45^{\circ}$ to the principal directions of materials, the off-diagonal terms are related to wave velocity of the quasi-shear wave with propagation direction in direction $\mathrm{n}=\left(\frac{1}{\sqrt{2}} \frac{1}{\sqrt{2}}\right)^{T}(T$ superscript denotes quasi- transverse mode) and particle motion in the $i-j$ plane. The off-diagonal elasticity components $C_{i i j i}$ can be determined by equations 6 (Ozyhar et al., 2013).

$$
\begin{gathered}
C_{11}=V_{11}^{2} \rho \quad C_{22}=V_{22}^{2} \rho \quad C_{33}=V_{33}^{2} \rho \\
C_{44}=\left(V_{32}^{2} \rho+V_{23}^{2} \rho\right) / 2 \\
C_{55}=\left(V_{13}^{2} \rho+V_{31}{ }^{2} \rho\right) / 2 \\
C_{66}=\left(V_{12}{ }^{2} \rho+V_{21}{ }^{2} \rho\right) / 2 \\
C_{12}=\sqrt{\left.C_{11}+C_{66}-2 V_{12 / 12}^{2} \rho\right)\left(C_{22}+C_{66}-2 V_{12 / 12}^{2} \rho\right)}-C_{66} \\
C_{13}=\sqrt{\left.C_{11}+C_{55}-2 V_{13 / 13}^{2} \rho\right)\left(C_{33}+C_{55}-2 V_{13 / 13}^{2} \rho\right)}-C_{55} \\
C_{23}=\sqrt{\left.C_{22}+C_{44}-2 V_{23 / 23}^{2} \rho\right)\left(C_{33}+C_{44}-2 V_{23 / 23}^{2} \rho\right)}-C_{44}
\end{gathered}
$$

The compliance tensor $S$ of the orthotropic material is the inverse of the stiffness tensor $C$, i.e. $C^{-1}=S$. The compliance matrix is directly related to the elastic engineering parameters (Bucur and Archer, 1984):

$$
S i j=\left[\begin{array}{cccccc}
S_{11}=1 / E_{1} & S_{12}=-v_{12} / E_{2} & S_{13}=-v_{13} / E_{3} & 0 & 0 & 0 \\
S_{21}=-v_{21} / E_{1} & S_{22}=1 / E_{2} & S_{23}=-v_{23} / E_{3} & 0 & 0 & 0 \\
S_{31}=-v_{31} / E_{2} & S_{32}=-v_{32} / E_{2} & S_{33}=1 / E_{3} & 0 & 0 & 0 \\
0 & 0 & 0 & S_{44}=1 / G_{23} & 0 & 0 \\
0 & 0 & 0 & 0 & S_{55}=1 / G_{13} & 0 \\
0 & 0 & 0 & 0 & 0 & S_{66}=1 / G_{12}
\end{array}\right]
$$

Three Young's moduli of $E_{1}, E_{2}, E_{3}$ refer to the principal directions of materials, three shear moduli $G_{12}, G_{13}, G_{23}$ refer to principal planes of materials (symmetry), and out of six Poisson's ratios $n_{12}, n_{21}, n_{13}, n_{31}$, $n_{23}, n_{32}$, the first index of Poisson's ratio refers to the (passive) strain and the second index refers to the active strain. Bucur and Archer (1984) have described in detail the conversion between the components of the compliance matrix and the components of the stiffness matrix.

\section{MATERIALS AND METHODS}

\section{MATERIJALI I METODE}

\subsection{Materials}

3.1. Materijali

Poplar (Populus deltoides) trees, as a fast-growing species and widely planted in Iran, with an average DHB of 20-25 cm, were harvested from Chamestan Educational Forest, Noor, Iran. Logs were cut into 120 $\mathrm{cm}$ length and debarked by hand (Figure 1). The average wood density was $0.39 \mathrm{~g} / \mathrm{cm}^{3}$. The morphological characteristics and chemical composition of Poplar wood are listed in Table 1.

\subsection{Panel manufacturing}

3.2. Proizvodnja ploča

The veneers with thickness of $0.6 \mathrm{~mm}$ were prepared from poplar wood and then cut into strands with $30 \mathrm{~mm}$ width and $120 \mathrm{~mm}$ length by circular saw. The strands were dried at $(105 \pm 5){ }^{\circ} \mathrm{C}$ in an oven to reach moisture content of 2.5-3\%. Phenol-formaldehyde 


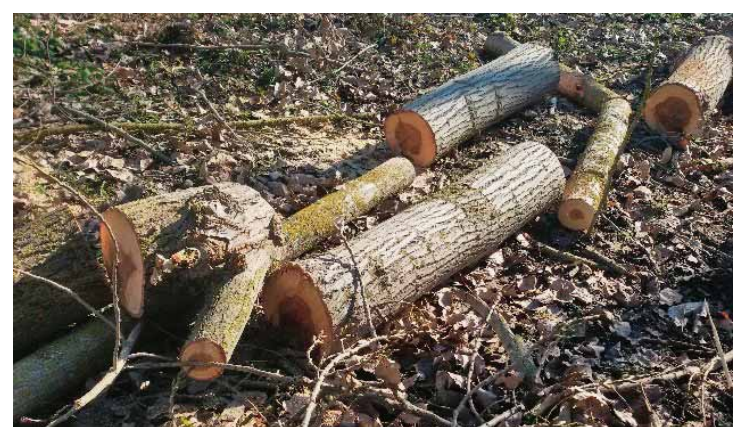

Figure 1 Harvesting and debarking Poplar tree

Slika 1. Sječa, izrada i otkoravanje drva topole

Table 1 Morphological characteristics and chemical composition of Poplar wood (Ramazani et al., 2013)

Tablica 1. Morfološka svojstva i kemijski sastav drva topole (Ramazani et al., 2013.)

\begin{tabular}{|l|c|}
\hline Properties / Svojstva & $\begin{array}{c}\text { Poplar } \\
\text { Topola }\end{array}$ \\
\hline Anatomical / Anatomska & \\
\hline Fiber length / duljina vlakna, mm & $0.76(0.087)^{*}$ \\
\hline $\begin{array}{l}\text { Fiber lumen diameter / promjer lumena } \\
\text { vlakna, } \mu \mathrm{m}\end{array}$ & $15.67(1.81)$ \\
\hline Fiber overall diameter / promjer vlakna, $\mu \mathrm{m}$ & $23.00(2.5)$ \\
\hline $\begin{array}{l}\text { Fiber wall thickness / debljina stijenke } \\
\text { vlakna, } \mu \mathrm{m}\end{array}$ & $3.6(0.59)$ \\
\hline Chemical / Kemijska & 51 \\
\hline Cellulose / celuloza, \% & 22.3 \\
\hline Lignin / lignin, \% & 5.1 \\
\hline Extractives / ekstraktivne tvari, \% & 0.7 \\
\hline Ash / pepeo, \% & \\
\hline
\end{tabular}

${ }^{a}$ Dissolved in alcohol-acetone. / Otopljeno u alkohol-acetonu.

* Values in parenthesis are the standard deviation. / Vrijednosti $u$ zagradama standardne su devijacije.

(PF) resin was used at a level of $8 \%$ based on oven-dry weight of wood strands to produce the panels. No wax or other additives were used. The characteristics of the PF resin are given in Table 2.

Table 2 Properties of PF resin

Tablica 2. Svojstva fenol-formaldehidne (PF) smole

\begin{tabular}{|l|c|}
\hline Properties / Svojstva & PF \\
\hline Color / boja & Dark / tamna \\
\hline $\begin{array}{l}\text { Solid content / sadržaj čvrste tvari, } 105^{\circ} \mathrm{C}, \\
3 \mathrm{H}, \%\end{array}$ & 62.00 \\
\hline Density / gustoća, $\mathrm{g} / \mathrm{cm}^{3}$ & 1.13 \\
\hline $\mathrm{PH} 25^{\circ} \mathrm{C}$ & 7.25 \\
\hline Viscosity / viskoznost, $20^{\circ} \mathrm{C}, \mathrm{cPas}$ & 320 \\
\hline Gel time / vrijeme geliranja, $100^{\circ} \mathrm{C}, \mathrm{s}$ & 300 \\
\hline
\end{tabular}

OSB panels were manufactured using a standardized procedure that simulated industrial production at the laboratory. For the preparation of the panels, strands $(120 \mathrm{~mm} \times 30 \mathrm{~mm} \times 0.6 \mathrm{~mm})$ were mixed in a rotary blender equipped with resin spraying. The strands were oriented manually into a forming box and then the strands mats were hot-pressed at pressure of $3.43 \mathrm{~N} /$ $\mathrm{mm}^{2}$ and temperature of $190{ }^{\circ} \mathrm{C}$ for 10 minutes. The dimensions of the panels were $460 \mathrm{~mm} \times 460 \mathrm{~mm} \times 16$ $\mathrm{mm}$. Target board density was set at $760 \mathrm{~kg} / \mathrm{m}^{3}$. The
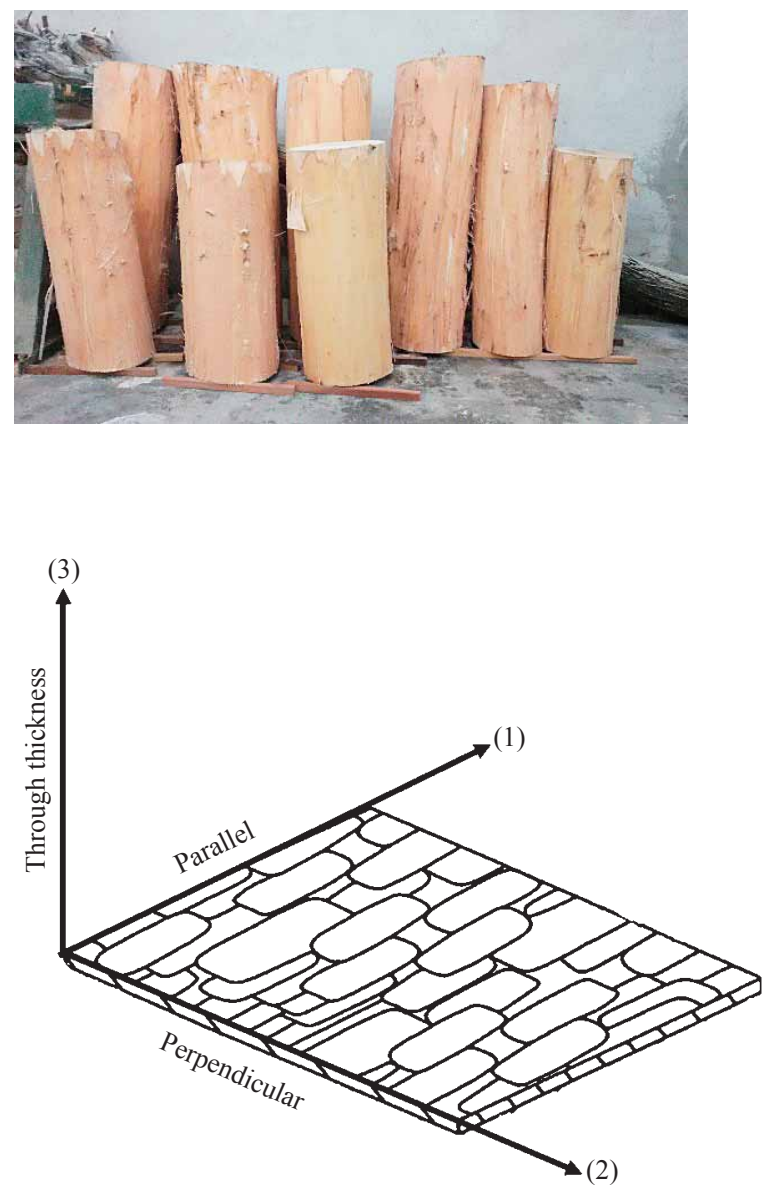

Figure 2 Schematic of principal axes of OSB

Slika 2. Shematski prikaz glavnih osi OSB ploče

manufactured panels were conditioned at relative humidity of $(65 \pm 5) \%$ and temperature of $(20 \pm 3){ }^{\circ} \mathrm{C}$. The OSB panels are assumed as an elastic, anisotropic wood composite material with orthotropic symmetry, where the symmetry planes are defined in terms of parallel direction of strand alignment (direction 1), perpendicular direction of strand alignment (direction 2) and thickness of the panel (direction 3) (Figure 2).

\subsection{Ultrasonic tests}

3.3. Ultrazvučni testovi

Four types of samples with different orientations to the major axis of anisotropy for ultrasonic testing were of cubical shape with $16 \mathrm{~mm}$ edge length (Figure 3 ). For each sample, 6 replications and a total of twenty-four samples were provided. Density of all samples was kept at $0.76 \mathrm{~g} / \mathrm{cm}^{3}$. Prior to testing, all the specimens were conditioned at a temperature of $(20 \pm 3){ }^{\circ} \mathrm{C}$ and a relative humidity $(\mathrm{RH})$ of $(65 \pm 5) \%$ to ensure uniform moisture content.

In the present study, orthotropic symmetry was assumed for elastic properties of the OSBs. According to Bucur (2006), three longitudinal and three shear wave velocities propagating along the principal axes of anisotropy, and also three quasi-longitudinal or quasi-shear wave velocities, measured at the angle $\theta$ of the wave orientation vector, are needed in order to determine all independent components of the stiffness matrix. In this research, three longitudinal waves (Vii), six shear waves 


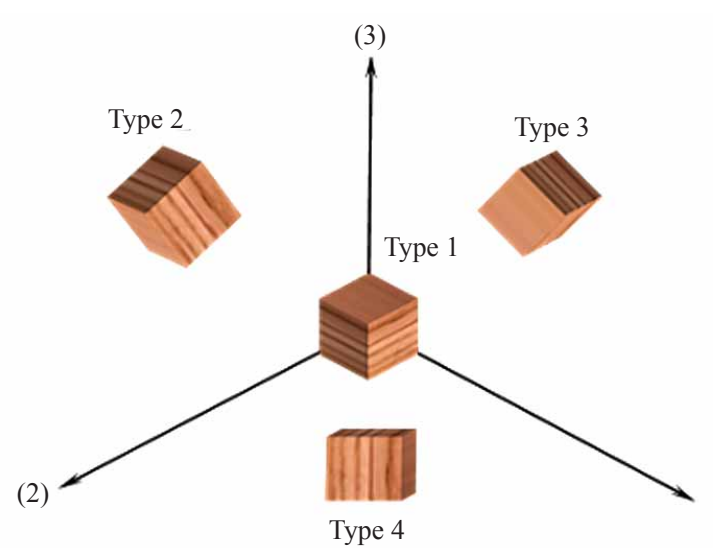

Figure 3 Types of specimens used for ultrasound velocity measurements in different orientations

Slika 3. Vrste uzoraka rabljenih za ultrazvučna mjerenja brzina različitih smjerova

$(\mathrm{Vij})$ and three quasi-shear waves at $45^{\circ}(\mathrm{Vij} / \mathrm{ij})$ were measured. The equipment used for performing ultrasonic measurements consists of a digital oscilloscope (WaveRunner 62Xi, Lecroy Corporation, Chestnut Ridge, NY, USA), a pulser-receiver (5077 PR, Panametrics Inc., Waltham, MA, USA), two pairs of transducers with frequencies of $100 \mathrm{kHz}$ and $250 \mathrm{kHz}$ for longitudinal and transversal waves, respectively, as well as an auxiliary testing device (Figure 4). For better contact between the transducers and the specimens, a thin layer of honey was used. A cellophane film was applied in order to prevent the infiltration of honey into the wood microstructure, and hence influencing its stiffness properties. In this study, through-transmission technique was used to determine the ultrasonic wave velocities. In this technique, two transducers are used, one sending a signal into the specimen and one receiving the sent signal on the opposite side of the specimen (Figure 4).

As reported by continuum (micro) mechanics (Salençon, 2001; Zaoui, 2002), ultrasound-derived elastic properties of micro-heterogeneous materials are defined by a representative volume element (RVE). Thus, the characteristic length of the $\operatorname{RVE}\left(L_{\mathrm{RVE}}\right)$ must be considerably larger than the length of inhomogeneities $d$ inside the $\operatorname{RVE}\left(L_{\mathrm{RVE}} \gg d\right)$, and the characteristic length of the RVE $\left(L_{\mathrm{RVE}}\right)$ need to be smaller than the wavelength $\lambda$ of the propagation waves $\left(L_{\mathrm{RVE}} \ll \lambda\right)$. Mathematically, this is expressed by means of the separationof-scales requirement (Kohlhauser and Hellmich, 2013),

$$
d \gg L_{\mathrm{RVE}} \ll \lambda
$$

The wavelength $\lambda$ is readily accessible from the measured wave speed $V$ and from the chosen signal frequency $f$ as $\lambda=\mathrm{V} / f$. The wave speed is equal to the travel distance $s$ of the wave divided by the travel time $t$ of the signal $V=S / t$.

\section{RESULTS AND DISCUSSION 4. REZULTATI I RASPRAVA}

Homogenized material properties of micro-heterogeneous materials are defined on representative vol-

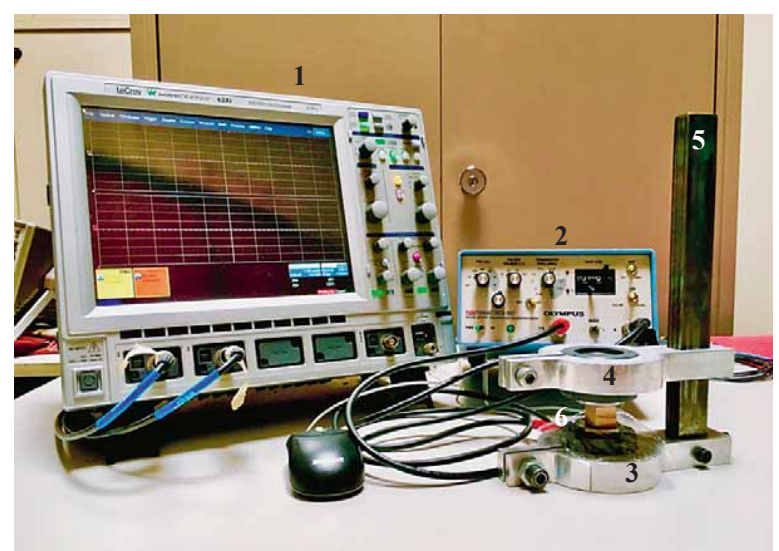

Figure 4 Ultrasonic equipment: 1. oscilloscope, 2. pulserreceiver, 3. transducer sender, 4. transducer receiver, 5. auxiliary testing device, 6 . sample

Slika 4. Oprema za ultrazvučna mjerenja: 1. osciloskop, 2. prijamnik impulsa, 3. pretvornik-predajnik, 4. pretvornikprijamnik, 5. pomoćni uređaj za ispitivanje, 6 . uzorak

ume elements (RVEs). The inhomogenities within an RVE of OSB result from the strands made from Poplar wood with an average fiber lumen diameter of 15.67 $\mu \mathrm{m}$ (Table 1). Thus, the minimum longitudinal and shear wavelength amounted to 9.3 and $3 \mathrm{~mm}$, respectively, and the length of RVE $\approx 0.76 \mathrm{~mm}$ (Table 4). In this study, it is implied that the characteristic length of $\operatorname{RVE}\left(L_{\mathrm{RVE}}\right)$ is considerably larger than the lumen diameter of Poplar strands (d) inside the RVE, and $L_{\mathrm{RVE}}$ is smaller than both longitudinal and shear wavelength values. Consequently, the separation of scales requirement is fulfilled, and the measured velocities can be used to determine the elastic properties of the OSB.

The mean values and standard deviations of density and ultrasonic wave velocities are given in Table 3 , and the corresponding wavelengths are given in Table 4. The maximum and minimum longitudinal wave velocities amounted to $V_{11}=4.2$ and $V_{33}=0.93 \mathrm{~km} / \mathrm{s}$, respectively $\left(V_{11}>V_{22} \gg V_{33}\right)$. This means that strands were predominantly oriented in the principal axis of the boards and they behaved as orthotropic materials. The velocities are related to the material elasticity, because the propagation of the wave generates mechanical oscillations (Keunecke et al., 2007). As reported in literature (Bucur, 2006; Bucur and Archer, 1984; Gerhards, 1982), the velocities in thickness direction $\left(V_{33}\right)$ are significantly lower than in parallel and perpendicular to manufacturing direction, respectively. In thickness direction $\left(V_{33}\right)$, there is no continuous medium to make it possible to conduct the wave, so velocity is always lower in this direction.

The values of shear wave velocities with directions of propagation and polarization in the same symmetry plane are unequal. The different values for each shear wave velocities proved the anisotropy of OSBs. Generally, longitudinal wave velocities are higher than shear wave velocities, because the particle oscillations are parallel to the direction of longitudinal wave propagation, while they are perpendicular to each other in shear waves (Wang, 20013; Wang et al., 2007; Zhang et al., 2011). Wood-based panel anisotropy could be 
Table 3 Mean values of density and ultrasonic wave velocities in OSB

Tablica 3. Srednje vrijednosti gustoće i brzina ultrazvučnih valova u OSB ploči

\begin{tabular}{|c|c|c|c|c|c|c|c|c|c|c|c|c|}
\hline $\begin{array}{l}\text { Density } \\
\text { Gustoća }\end{array}$ & $\begin{array}{r}\text { Longitu } \\
U z d\end{array}$ & $\begin{array}{l}\text { dinal wa } \\
\text { užni val, }\end{array}$ & $\begin{array}{l}\text { ve, } \mathbf{k m} / \mathbf{s} \\
\mathrm{km} / \mathrm{s}\end{array}$ & & & $\begin{array}{l}\text { Shear w: } \\
\text { Poprečni }\end{array}$ & $\begin{array}{l}\text { val, } \mathbf{k m} / \mathrm{km} / \\
\text { vals }\end{array}$ & & & $\begin{array}{l}\text { Quasi- } \\
\text { Kvazip }\end{array}$ & $\begin{array}{l}\text { hear wa } \\
\text { prečni }\end{array}$ & $\begin{array}{l}\mathrm{e}, \mathbf{k m} / \mathbf{s} \\
l, \mathrm{~km} / \mathrm{s}\end{array}$ \\
\hline $\begin{array}{c}\text { Mean } \\
\text { value } \\
\text { Srednja } \\
\text { vrijednost }\end{array}$ & $V_{11}$ & $V_{22}$ & $V_{33}$ & $V_{12}$ & $V_{21}$ & $V_{13}$ & $V_{31}$ & $V_{23}$ & $V_{32}$ & $V_{12 / 12}$ & $V_{21 / 21}$ & $V_{13 / 13}$ \\
\hline $\begin{array}{c}0.76 \\
( \pm 0.08)^{\mathrm{a}}\end{array}$ & $\begin{array}{c}4.2 \\
( \pm 0.16)\end{array}$ & $\begin{array}{c}3.39 \\
( \pm 0.11)\end{array}$ & $\begin{array}{c}0.93 \\
( \pm 0.05)\end{array}$ & $\begin{array}{c}1.8 \\
( \pm 0.55)\end{array}$ & $\begin{array}{c}1.67 \\
( \pm 0.36)\end{array}$ & $\begin{array}{c}1.03 \\
( \pm 0.08)\end{array}$ & $\begin{array}{c}1.72 \\
( \pm 1.09)\end{array}$ & $\begin{array}{c}0.75 \\
( \pm 0.21)\end{array}$ & $\begin{array}{c}0.83 \\
( \pm 0.17)\end{array}$ & $\begin{array}{c}1.58 \\
( \pm 0.13)\end{array}$ & $\begin{array}{c}1.00 \\
( \pm 0.08)\end{array}$ & $\begin{array}{c}0.97 \\
( \pm 0.03)\end{array}$ \\
\hline
\end{tabular}

a Values in parenthesis are the standard deviation. / Vrijednosti u zagradama standardne su devijacije.

Table 4 Mean values of wavelengths in OSB

Tablica 4. Srednje vrijednosti valnih duljina u OSB ploči

\begin{tabular}{|c|c|c|c|c|c|c|c|c|c|c|c|}
\hline \multicolumn{10}{|c|}{ Wavelength / Valna duljina, $\mathrm{mm}$} \\
\hline$\lambda_{11}$ & $\lambda_{22}$ & $\lambda_{33}$ & $\lambda_{12}$ & $\lambda_{21}$ & $\lambda_{13}$ & $\lambda_{31}$ & $\lambda_{23}$ & $\lambda_{32}$ & $\lambda_{12 / 12}$ & $\lambda_{13 / 13}$ & $\lambda_{23 / 23}$ \\
\hline 42 & 33.9 & 9.3 & 7.2 & 6.68 & 4.12 & 6.88 & 3.00 & 3.32 & 6.32 & 4 & 3.9 \\
\hline
\end{tabular}

Table 5 Anisotropy of OSB expressed by velocity ratios in principle anisotropic directions and planes

Tablica 5. Anizotropija OSB ploče izražena odnosima brzina u glavnim anizotropnim smjerovima i ravninama

\begin{tabular}{|c|c|c|c|c|c|}
\hline \multicolumn{2}{|c|}{$\begin{array}{c}\text { Anisotropy in principal directions } \\
\text { Anizotropija u glavnim smjerovima }\end{array}$} & $\begin{array}{c}\text { Anisotropy in symmetry planes } \\
\text { Anizotropija u simetričnim } \\
\text { ravninama }\end{array}$ & $\begin{array}{c}\text { Birefringence } \\
\text { in the same plane } \\
\text { Dvostruka refrakcija } u \text { istoj ravnini }\end{array}$ \\
\hline $\begin{array}{c}\text { Longitudinal waves } \\
\text { velocities } \\
\begin{array}{c}\text { Brzine uzdužnih } \\
\text { valova }\end{array}\end{array}$ & $\begin{array}{c}\text { Ratios } \\
\text { Omjeri }\end{array}$ & $\begin{array}{c}\text { Shear waves } \\
\text { velocities } \\
\text { Brzine poprečnih } \\
\text { valova }\end{array}$ & $\begin{array}{c}\text { Ratios } \\
\text { Omjeri }\end{array}$ & $\begin{array}{c}\text { Shear waves } \\
\text { velocities } \\
\text { Brzine poprečnih } \\
\text { valova }\end{array}$ & $\begin{array}{c}\text { Ratios } \\
\text { Omjeri }\end{array}$ \\
\hline$V_{11} / V_{22}$ & 1.23 & $V_{12} / V_{13}$ & 1.74 & $V_{12} / V_{21}$ & 1.07 \\
\hline$V_{11} / V_{33}$ & 4.5 & $V_{13} / V_{23}$ & 2.4 & $V_{13} / V_{31}$ & 1.7 \\
\hline$V_{22} / V_{33}$ & 3.64 & $V_{13} / V_{23}$ & 1.37 & $V_{23} / V_{32}$ & 0.9 \\
\hline
\end{tabular}

calculated by the ratios between velocities of longitudinal and shear waves in the three main symmetry directions (Bucur, 2006). The anisotropy of OSB can be deduced from the values noted in Table 5. $V_{12} / V_{21}=1.07$ shows a low anisotropy in 1-2 plane. The highest anisotropy expressed by birefringence is in 1-3 plane. Bucur et al. (1998) argued that the anisotropy is much higher in planes containing the axis 3 , and that it is related to the type and size of the particles.

Calculated stiffness properties are summarized in Table 6. The stiffness tensor components are arranged as follows:

$$
C_{11}>C_{22} \gg C_{33}, C_{66}>C_{55}>C_{44} \text {, and } C_{12} \gg C_{13}>C_{23}
$$

The order of the stiffness coefficients is related to the theoretical acoustic behavior and mechanical properties of wood and its composites (Goncalves et al., 2011). The shear stiffness in the plane of the board $C_{66}$ $(2.31 \mathrm{GPa})$ is greater than the shear stiffnesses in the out-of-plane directions, where $C_{44}(0.47 \mathrm{GPa})$ is smaller than $C_{55}(1.44 \mathrm{GPa})$. The stiffness tensor components derived from ultrasonic tests are in the same order of magnitude as the values reported by Bucur et al. (1998), who worked on elastic constants of OSB, MDF and chipboard using ultrasonic velocity method (Table 6). Kazemi Najafi et al. (2005) also determined elastic constants of two types of commercial particleboards by means of ultrasonic technique, and they obtained a similar trend for stiffness coefficients. The values of stiffness components in this study are greater (13-44 \%) than the stiffness values obtained by Bucur et al. (1998) (Table 6).

The values of engineering elastic constants of OSB are given in Table 7 . The modulus of elasticity in parallel direction (refer to Figure 2) $\left(E_{1}\right)$ is $7.14 \mathrm{GPa}$, which is 29 $\%$ greater than the modulus of elasticity in perpendicular direction $\left(E_{2}\right)(5 \mathrm{GPa})$. Bucur et al. (1998) reported that the $E_{1}$ in OSB is $20 \%$ higher than $E_{2}$ and Kazemi Najafi et al. (2005) also obtained the $E_{1} 17 \%$ higher than $E_{2}$ in particleboard. The minimum modulus of elasticity amounted to $0.5 \mathrm{GPa}$ in thickness direction $\left(E_{3}\right)$.

The literature, there are few references about modulus of elasticity in the perpendicular and thickness directions, shear modulus and Poisson's ratio. Mostly, the modulus of elasticity in the direction of strand alignment was measured in static tests on OSBs. Furthermore, the comparability between the measurement results obtained in this study with other results is generally complicated and unreliable since different manufacturing processes, glues, densities, specimen dimensions, frequencies and measurement techniques are used in the majority of cases.

In this study, shear modulus obtained from ultrasonic results, in parallel, perpendicular and thickness 
Table 6 Mean values and standard deviation of stiffness tensor components derived from ultrasonic testing according to Equations 4, 5 and 6

Tablica 6. Srednje vrijednosti i stadardne devijacije krutosti komponente tenzora derivirane iz ultrazvučnih ispitivanja prema jednadžbama 4 , 5 i 6

\begin{tabular}{|c|c|c|c|c|}
\hline $\begin{array}{c}\text { Diagonal stiffness tensor } \\
\text { components } \\
\begin{array}{c}\text { Komponente tenzora } \\
\text { dijagonalne krutosti }\end{array}\end{array}$ & $\begin{array}{c}\text { Mean value, GPa } \\
\text { Srednja vrijednost, } \\
\mathrm{GPa}\end{array}$ & $\begin{array}{c}\text { Mean value }, \mathbf{G P a} \\
\text { Srednja vrijednost } \\
\mathrm{GPa}\end{array}$ & $\begin{array}{c}\text { Off-diagonal stiffness } \\
\text { tensor components } \\
\text { Komponente tenzora } \\
\text { izvandijagonalne krutosti }\end{array}$ & $\begin{array}{c}\text { Mean value } \mathbf{A}^{\#}, \mathbf{G P a} \\
\text { Srednja vrijednost } \\
\text { GPa }\end{array}$ \\
\hline$C_{11}$ & $13.4( \pm 0.86)^{\mathrm{a}}$ & 9.6 & $C_{12}$ & $7.02( \pm 0.34)$ \\
\hline$C_{22}$ & $8.8( \pm 0.41)$ & 6.5 & $C_{13}$ & $1.34( \pm 0.14)$ \\
\hline$C_{33}$ & $0.66( \pm 0.08)$ & 0.33 & $C_{23}$ & $1.06( \pm 0.11)$ \\
\hline$C_{44}$ & $0.47( \pm 0.07)$ & 0.31 & & \\
\hline$C_{55}$ & $1.44( \pm 0.09)$ & 0.8 & & \\
\hline$C_{66}$ & $2.31( \pm 0.12)$ & 2.00 & & \\
\hline
\end{tabular}

${ }^{a}$ Values in parenthesis are the standard deviation. / Vrijednosti u zagradama standardne su devijacije.

* Bucur and Archer (1984)

Table 7 Elastic engineering parameters determined from ultrasonic measurements

Tablica 7. Parametri elastičnosti određeni iz ultrazvučnih mjerenja

\begin{tabular}{|c|c|c|c|c|c|c|c|c|c|c|c|}
\hline \multicolumn{3}{|c|}{$\begin{array}{c}\text { Young's modulus, GPa } \\
\text { Youngov modul, GPa }\end{array}$} & \multicolumn{3}{|c|}{$\begin{array}{l}\text { Shear modulus, GPa } \\
\text { Modul smicanja, GPa }\end{array}$} & \multicolumn{6}{|c|}{$\begin{array}{l}\text { Poisson's ratios } \\
\text { Poissonovi omjeri }\end{array}$} \\
\hline$E_{1}$ & $E_{2}$ & $E_{3}$ & $G_{12}$ & $G_{13}$ & $G_{23}$ & $v_{12}$ & $v_{21}$ & $v_{13}$ & $v_{31}$ & $v_{23}$ & $v_{32}$ \\
\hline 7.14 & 5 & 0.5 & 2.32 & 1.43 & 0.47 & 0.66 & 0.46 & 0.93 & 0.06 & 0.7 & 0.07 \\
\hline
\end{tabular}

direction, are about $E 1 / 3, E 1 / 5$ and $E 1 / 15$, respectively. The values of Poisson's ratios were obtained from the literature, i.e. 0.23 in bending test in 1-3 plane (Ting and Chen, 2005), and Bucur (1992) measured the value of Poisson's ratio from 0.068 to 1.52 in flakboard. For validation of the obtained Poisson's ratios in this study, Poisson's ratio can be estimated as (Kazemi Najafi et al., 2005; Bucur, 1992):

$$
\begin{aligned}
& \left(1-v_{12} \cdot v_{21}\right)>0 \\
& \left(1-v_{13} \cdot v_{31}\right)>0 \\
& \left(1-v_{23} \cdot v_{32}\right)>0
\end{aligned}
$$

And the

$$
\left(1-v_{12} \cdot v_{21}-v_{13} \cdot v_{31}-v_{23} \cdot v_{32}-2 \cdot v_{21} \cdot v_{32} \cdot v_{31}\right)>0
$$

As a result, these conditions are satisfied and it can be deduced that the coefficients are valid in ultrasonic range of measurement. Theoretically, Poisson's ratios for anisotropic materials with orthotropic symmetry can have no bounds (Ting and Chen, 2005). In the present study, there are no values exceeding 1.00 for Poisson's ratios, while Ozyhar et al. (2013) and Bucur (1992) obtained Poisson's ratios with values exceeding 1.00. They stated that Poisson's ratios with values higher than one are assumed to be unusual for wood and wood composites, and they have not been reported in static tests. Kohlhauser and Hellmich (2012) and Bader et al. (2016) argued that the ultrasonic characterization of off-diagonal stiffness components is very sensitive to inaccuracies regarding the wave velocity measurements and, to solve this problem, they proposed a combined ultrasonic-mechanical method to obtain the Poisson's ratios.

\section{CONCLUSION}

5. ZAKLJUČAK

Engineering elastic parameters of OSB made from Poplar were studied using ultrasonic contact pulse transmission. The ultrasonic contact pulse transmission shows great potential to determine the characterization of elastic wave velocity, stiffness and engineering elastic parameters and also study the anisotropic behavior of OSB, as an easy, fast, reliable and economic method, since few information can be found in the literature about elastic constants (stiffness, shear modulus and Poisson's ratios) of OSB. Based on the findings of this study, the measured velocity $V_{11}$ was 19 and 78 percent higher than $V_{22}$ and $V_{33}$, respectively. Generally, the highest velocity was measured in the direction of strands alignment, and on the other hand, the lowest velocity was that of shear waves, observed in the transverse plane. The normal stiffness in thickness direction, $C_{33}$, was considerably lower than the normal stiffness in the plane of the board. The obtained order of stiffness tensor components was $C_{11}>C_{22} \gg C_{33}, C_{66}>C_{55}$ $>C_{44}$. The ratio of longitudinal and shear velocities showed the highest anisotropy in 1-3 plane. The highest values of Young's modulus and shear modulus were calculated for $E_{1}$ and $G_{12}$. The value of Poisson's ratio ranged between 0.06 and 0.93 .

\section{REFERENCES}

\section{LITERATURA}

1. Bader, T. K.; Dastoorian, F.; Ebrahimi, G.; Unger, G.; Lahayne, O.; Hellmich, C.; Pichler, B., 2016: Combined ultrasonic-mechanical characterization of orthotropic elastic properties of an unrefined bagasse fiber-polypro- 
pylene composite, Composites, Part B, 95: 96-104. https://doi.org/10.1016/j.compositesb.2016.03.070.

2. Bodig, J.; Jayne, B. A., 1993: Mechanics of wood and wood composites. Krieger Publishing Company, Malabar. https://trove.nla.gov.au/work/22349993.

3. Bucur, V., 1992: Anisotropy characterization of structural flakeboards with ultrasonic methods. Wood Fiber Science, 24: 337-346.

https://wfs.swst.org/index.php/wfs/article/view/784.

4. Bucur, V., 2006: Acoustics of wood, $2^{\text {nd }}$ edition. Springer Series in Wood Science. Springer. https://doi.org/10.1007/3-540-30594-7.

5. Bucur, V.; Ansell, M. R.; Barlow, C. Y.; Pritchard, J.; Garros, S.; Deglise, X., 1998: Physical methods for characterizing wood composite panel products. Holzforschung, 52: 553-561. https://doi.org/10.1515/hfsg.1998.52.5.553.

6. Bucur, V.; Archer, R., 1984: Elastic-constants for wood by an ultrasonic method. Wood Science Technology, 18: 255-265. https://doi.org/10.1007/BF00353361.

7. Gerhards, C. C., 1982: Effect of moisture content and temperature on the mechanical properties of wood: an analysis of immediate effects. Wood Fiber Science, 4: 4-36. https://wfs.swst.org/index.php/wfs/article/view/501.

8. Goncalves, R.; Trinca, A. J.; Cerri, D. G. P., 2011: Comparison of elastic constants of wood determined by ultrasonic wave propagation and static compression testing. Wood Fiber Science, 43: 64-75. https://wfs.swst.org/index.php/wfs/article/view/1247.

9. Goncalves, R.; Trinca, A. J.; Pellis, B. P., 2014: Elastic constants of wood determined by ultrasound using three geometries of specimens. Wood Science Technology, 48: 269-287. https://doi.org/10.1007/s00226-013-0598-8.

10. Hiziroglu, S., 2006: Oriented strand board as a building material. Oklahoma State University Extension Fact Sheet, FAPC-146, Food and Agricultural Products Research Center.

11. Kazemi Najafi, S.; Bucur, V.; Ebrahimi, G., 2005: Elastic constants of particleboard with ultrasonic technique, Materials Letters, 59: 2039-2042.

https://doi.org/10.1016/j.matlet.2005.02.013.

12. Keunecke, D.; Sonderegger, W.; Pereteanu, K.; Lüthi, T.; Niemz, P., 2007: Determination of young's and shear moduli of common yew and Norway spruce by means of ultrasonic waves. Wood Science Technology, 41: 309327. https://doi.org/10.1007/s00226-006-0107-4.

13. Kohlhauser, C.; Hellmich, C., 2012: Determination of Poisson's ratios in isotropic, transversely isotropic, and orthotropic materials by means of combined ultrasonicmechanical testing of normal stiffnesses: application to metals and wood. European Journal Mechanics A-Solid, 33, 82-98. https://doi.org/10.1016/j.euromechsol.2011.11.009.

14. Kohlhauser, C.; Hellmich, C., 2013: Ultrasonic contact pulse transmission for elastic wave velocity and stiffness determination: Influence of specimen geometry and porosity. Engineering Structures, 47: 115-133.

https://doi.org/10.1016/j.engstruct.2012.10.027.

15. Morris, V.; Gustafsson, P. J.; Serrano, E., 1995: The shear strength of light-weight beams with and without a hole- a preliminary study. Workshop on mechanical properties of panel products, Watford, UK.

16. Ozyhar, T.; Hering, S.; Sanabria, S. J.; Niemz, P., 2013: Determining moisture-dependent elastic characteristics of beech wood by means of ultrasonic waves. Wood Science Technology, 47: 329-341. https://doi.org/10.1007/s00226-012-0499-2.

17. Ramazani, S.; Talaeipour, M.; Aliabadi, M.; Tabeei, A.; Bazyar, B., 2013: Investigation of the anatomical, biometry and chemical characteristics of juvenile and mature poplar (Populus Alba) wood. Iranian Journal of Wood and Paper Science Research, 28: 182-193. https://www. sid.ir/fa/journal/ViewPaper.aspx?id=190256.

18. Salençon, J., 2001: Handbook of Continuum Mechanics. Springer, Berlin Heidelberg, Germany. https://doi.org/10.1007/978-3-642-56542-7.

19. Smulski, S., 1997: A Guide for Specifiers, Designer and Users. PFS Research Foundation: Madison, WI, USA Engineering Wood Product.

20. Ting, T. C. T.; Chen, T., 2005: Poisson's ratio for anisotropic elastic materials can have no bounds. The Quarterly Journal of Mechanics and Applied Mathematics, 58 : 73-82. https://doi.org/10.1093/qjmamj/hbh021.

21. Wang, X., 2013: Acoustic measurements on trees and logs: a review and analysis. Wood Science Technology, 47: 965975. https://doi.org/10.1007/s00226-013-0552-9.

22. Wang, X.; Ross, R. J.; Carter, P., 2007: Acoustic evaluation of wood quality in standing trees. Wood Fiber Science, 39: 28-38.

https://wfs.swst.org/index.php/wfs/article/view/299/299.

23. Zaoui, A., 2002: Continuum micromechanics: survey. Journal of Engineering Mechanics, 128: 808-816. https:// doi.org/10.1061/(ASCE)0733-9399(2002)128:8(808).

24. Zhang, H.; Wang, X.; Su, J., 2011: Experimental investigation of stress wave propagation in standing trees. Holzforschung, 65: 743-748. https://doi.org/10.1515/hf.2011.059.

\section{Corresponding address:}

\section{SAEED KAZEMI NAJAFI, Ph.D.}

Department of Wood and Paper Science and Technology Natural Resources Faculty

Tarbiat Modares University

Tehran, IRAN

e-mail: skazemi_najafi@yahoo.com,

SKAZEMI@modares.ac.ir 